\title{
University Hackathons: New Ways of Educational and Social Innovation. The Experience of the University of Salamanca
}

\author{
Teresa Martín García \\ Universidad de Salamanca \\ Fernando Almaraz Menéndez \\ Universidad de Salamanca
}

Hackathons' celebration in the educational context has become an interesting formula to promote new forms of teaching and learning and to include universities in the processes of social and business innovation. For that reason, more and more universities are launching this type of initiative, born in the environment of hackers and which have evolved to extend to all professional and academic fields.

This article describes the most outstanding results of the experience of participation of the University of Salamanca in hackathons over six years, as well as the main academic benefits that this type of technological meetings can bring to professors and students.

Keywords: hacker, social innovation, new teaching methodologies, new learning spaces, educational innovation, hackathon

\section{INTRODUCTION}

Since its inception, the hacker movement has not enjoyed a very good reputation for often being associated with vandalism or illegal acts. However, beyond these beliefs, the true origin of these 'hackers' is in the academic environment, specifically at the Massachusetts Institute of Technology (MIT) (Cabello, 2012). Since the term was developed in the 1960 s, there are many hackers that have not used their computer skills to promote social good (Limaza, 2002), but that is the exception. "Hackers have been interested in taking the appropriation of new information and communication technologies (NICT) to the field of collective cooperation and distributed benefit" (Pedreira, 2004).

Therefore, it could be said that the reality of the hacker community and its philosophy are linked to using the possibilities offered by the internet for the development of products such as free software and other technologies, based on sharing knowledge, skills and working in a collective manner. The benefits of this working formula can be seen in examples such as Linux, a totally free operating system created by the Finnish Linus Torvalds, with the help of more hackers (Martín, 2013). For this reason, the organization of this type of meeting is increasingly common, applied to all professional and knowledge areas (Sanz-Martos, 2017).

In 2014, the University of Salamanca began its participation in hackathons to bring students closer to the business world, promote their commitment to the world's great problems and involve them in new social innovation processes. 
In this work are collected the most outstanding aspects of the development of these initiatives and the main benefits that enable educational innovation in alternative learning spaces, all based on the experience of this university and based on the data and results obtained over 6 years. The article also presents a review of the influence of hacker culture on university education and on innovation processes from its origins through the compilation of literature related to the subject.

\section{DESCRIPTION OF THE EXPERIENCE}

\section{Backgrounds: From the Company to the University}

The word hackathon is the result of merging the terms hacker and marathon, since at the beginning of this type of encounter, the target audience were mainly computer scientists and hackers. The origin of this type of meetings is located in the United States, in Silicon Valley, and is linked to the need of corporations to accelerate innovation processes, find fresh ideas and seek talent, as noted in an interview by Michiel Das, founder of Hackathon Spain (website born in 2014 in Spain to register these events and advise on their organization): "for technology companies it was very difficult to find technical profiles, so they began to gather young people who were passionate about the code on Friday nights, they bought them some pizzas and challenged them to develop solutions". All the big companies were joining in the celebration of this type of meetings, which began to look for this new talent and ideas at the universities. This type of event stopped being a mere meeting of computer scientists and began to acquire a more social and inclusive approach. "Hackathons are no longer just meetings to program, but capturing their essence of sharing and exchanging ideas, they have adapted to solve social problems". (Sanz- Martos, 2017).

In Spain, one of the companies that has opted for this type of technological encounters with university ties is Telefónica, with the organization of HackForGood, an interuniversity hackathon that has as a main objective to solve social challenges.

\section{INTERUNIVERSITY HACKATHONS}

\section{The Experience of the University of Salamanca in HackForGood From an Academic Perspective}

HackForGood is an interuniversity hackathon of a social nature promoted by Telefónica, together with its network of Chairs and to which the University of Salamanca has been joining for 6 years, through MEDIALAB USAL.

The meeting takes place over three consecutive days in which different Spanish universities participate simultaneously. Participants must work in record time in solving certain challenges that can improve the world and the quality of life of people through technology. The best projects are awarded through different formulas. But the most important thing is that the organization supports its continuity and the training of its members in aspects such as entrepreneurship. Participating students are considered 'hackersforgood', that, as it is defined on the website of these encounter as "enthusiastic, positive, optimistic, stimulating young people, with ideas and initiatives facing the challenge of solving those problems that no one has yet solved through innovative technological solutions".

Currently, the hackathon is held simultaneously in 16 universities: University of Alicante, University of Extremadura, University of Castilla La Mancha, University of Las Palmas de Gran Canaria, Polytechnic University of Madrid, Complutense University of Madrid, University Rey Juan Carlos, University Carlos III of Madrid, International University of La Rioja, Francisco de Vitoria University, European University of Madrid, ESNE, Catholic University of Murcia, University of Salamanca, Pontifical University of Salamanca, University of Seville, Polytechnic University of Valencia, and the University of Vigo. The celebration of this hackathon is linked to the development of certain complementary training activities (talks, seminars, etc.) and events that are also held simultaneously in all headquarters via streaming.

\section{Environment: New Learning Spaces}

These types of activities require physical spaces that favour their development, that allow the interaction and collaborative work and that have adequate technological tools, well-defined work 
methodologies and experienced staff. The hackathons referred to in this article are held at MEDIALAB USAL, a multidisciplinary space of the University of Salamanca that has as a main objective to promote new ways of learning and teaching, through the use of new technologies, the promotion of creativity, collaborative work and from the fusion of art, science and society (Almaraz-Menéndez et al., 2016). Along with the multidisciplinary and technological character, MEDIALAB USAL has among its main tasks to be a constant link between the University and the society. Therefore, the activities are open to all types of public. In this way, the connection between professors and students of the University with all the agents of society (companies, institutions, workers, researchers...) is promoted.

MEDIALAB USAL focuses its work on the challenge of making extensive the technology to all areas and being of support to new forms of learning and education. To this, in its activities with new technologies, students and teachers are actively involved in training initiatives that always have a practical component ("you learn to do") and interdisciplinary and collaborative work are sought. In this way, it contributes to stimulating new forms of learning that help people to be prepared for another of the consequences of the digital era: self-learning and constant training.

\section{Participants: Work in Multidisciplinary Teams to Solve Social Challenges}

In these technological marathons the participants must work as a team; a formula that encourages "the development of individual and group skills from discussion among students, each one being responsible for their own learning" (Lucero, 2003).

In this way, students have the opportunity to experience aspects as important as the feeling of belonging to the group; favoring the constant exchange of ideas and the acquisition of commitments to achieve the goal set together.

For three days, students of all types of profiles and areas of knowledge (computing, design, communication, social work, biology, etc.) participate in the development of projects, together with people from outside the university who are also present at the hackathon (It is an open and free event). In this way, the work also acquires a social dimension, favoring contact with active professionals from different areas and the development of the humanistic dimension of the students (Mejía, 2007).

Through this formula of collaborative work, the culture of the first hackers and that feeling of belonging to a community that works for a common technological objective and its innovative spirit is very well appreciated. Not surprisingly, they are also considered as "true revolutionaries of information technologies, whose actions have allowed the remarkable technological development achieved by computer science and telecommunications" (Salcedo et al, 2011).

To facilitate the work of the teams, the ideal is that their training is carried out in a balanced way, distributing the professional and academic profiles that are available in the best possible way. It is important to dedicate the first moments of the hackathon to carry out this distribution task. Subsequently, the participants must choose the problem they are going to solve and, later, the development work of the project begins, which includes the ideation of the project, the development of the code, the image and application or web design, if necessary. 


\section{FIGURE 1 \\ HACKFORGOOD SALAMANCA WORK GROUPS}

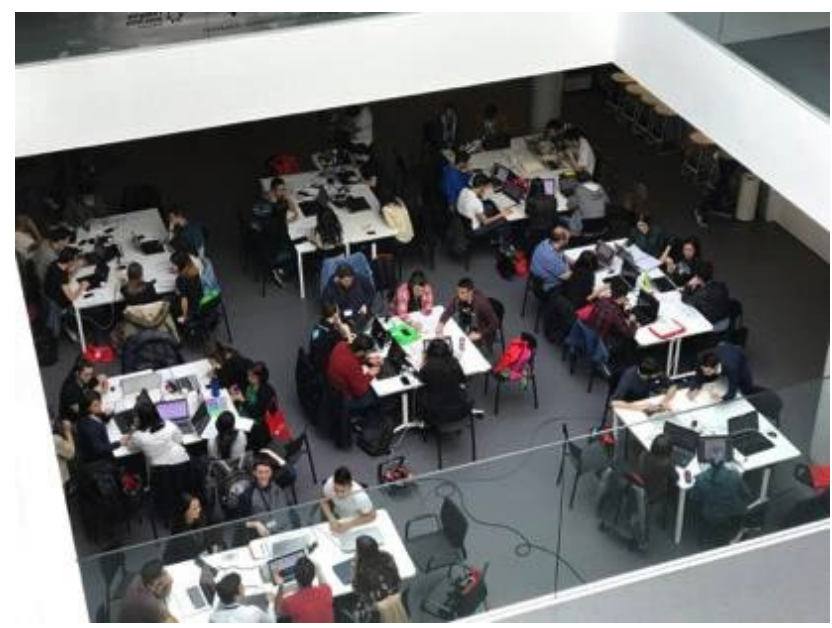

Once finished, on the last day of the hackathon you must present your proposal to the rest of the public to compete for the different prizes that are awarded. The awards reward the creativity of the proposal, the degree of development achieved, and innovation. The awards are very diverse (economic, in the form of academic or training scholarships, in collaborating companies and institutions).

\section{RESULTS}

\section{Alternative Ways of Learning: Innovative Methodologies Developed at HackForGood Salamanca}

New teaching methodologies are more and more present in the day-to-day classroom. However, sometimes, there are certain limitations that prevent developing them with the desired intensity or in the most appropriate way. This experience of participation allows us to affirm that hackathons have proven to be perfect activities to connect students with the business world and with the real problems of society (Amable et al., 2018).

Problem-based learning is one of the methodologies that are put into practice in these encounters, since the starting point is to solve certain problems or challenges in the real world. To get to some type of solution, students must analyze the case in depth from different perspectives, working collaboratively and going beyond the limits of theory. The student thus becomes an active subject and protagonist of its learning (Molina et al., 2003).

On the other hand, the teamwork formula in HackForGood enables cooperative learning for participating students, who during these days have to work together to achieve the same goal, acquiring different roles (leader, etc.) and tasks (Steinbeck, 2011).

The development of this hackathon is also connected with the Design Thinking methodology, which has its origins in Stanford University in California (USA), in the 70s and whose main objective is to generate innovative and effective ideas centered on people. "Design thinking focuses on the design process, rather than the final product" (Steinbeck, 2011).

Participating students also face the learning based on thinking, far from the simple memorization of concepts (Moraga and Soto, 2016), since for three days they must make quick decisions based on critical reasoning; to think more creatively and autonomously. In this way, they carry out an active, conscious and deeper learning.

\section{Acquisition of Skills and Competences}

In all the editions developed, an interesting growth of the student has been observed after their participation and the acquisition of numerous skills and competences. This is, mainly, due to the 
implementation of the aforementioned methodologies and since for a few days they have the opportunity to get closer to realities with which they otherwise have no contact (refugees, contamination of large cities in the world, certain diseases, etc).

There are many benefits of participating in this type of experience, and the academic, personal, cognitive and professional competences that they acquire, among the following stand out: creative resolution of problems, computational thinking, learning by doing, critical thinking, analytical ability, emotional intelligence, work organization ability, leadership, interpersonal relationship and communication, resolution of real problems, teamwork ability, self-critical ability, proactivity, entrepreneurial attitude, sense of social responsibility, innovation ability.

\section{University Students Who Improve the World. Some of the Most Outstanding Projects of HackForGood Salamanca}

Throughout these six years of experience in HackForGood, various projects have emerged from the University of Salamanca that have been selected in the top positions nationwide, achieving an important projection. These are some of the most outstanding examples.

\section{Pictochart: The WhatsApp of Pictograms}

This project was born from the request of a Salamanca association that works with people with intellectual disabilities, ASPRODES, and that they posed as a challenge to develop a communication system similar to WhatsApp that people with intellectual diversity could use. One of the hackathon working groups decided to work on this challenge and propose a possible solution that, in addition to obtaining different awards, continued to be developed by the association and some of the group's members.

\section{DataLab: Colombian Coffee Growers}

In the 2017 edition, another of the social projects that emerged in MEDIALAB USAL, Colombian Coffee Growers, obtained one of the national awards, the first national Luca award. This award is given to the best application based on the use of different databases on Colombia, provided by Telefónica and other collaborating organizations and institutions. After the development of this project, this working group has continued analyzing other types of data for the proposal of innovative solutions and they meet weekly at MEDIALAB USAL. One of its latest projects has focused on the analytics of cardiology data at the Salamanca Clinical Hospital to propose an algorithm that can help medical professionals to be faster with certain patient diagnoses.

\section{Bionic Lab: In My Hand}

This has been one of the most outstanding success cases of HackForGood Salamanca, so far. "In my hand" is a project based on the development of a bionic exoskeleton, which allows people who have lost mobility in one of their hands to perform certain movements that otherwise could not or, even, the rehabilitation through an app. The project arose from the challenge posed by a mother whose daughter did not have mobility in one of her hands and who had tried different solution options without success. This device allows the performance of tasks such as picking up objects and other types of daily movements such as tying shoes, which previously could not perform.

The members of this team decided to keep working on the development of the project started during the hackathon and, to promote it, they have participated in various national and international entrepreneurship programs; in fact, thanks to one of these initiatives they were able to access a stay for social entrepreneurs in Silicon Valley. 
FIGURE 2

INITIAL TESTS OF THE BIONIC ARM IN HACKFORGOOD SALAMANCA

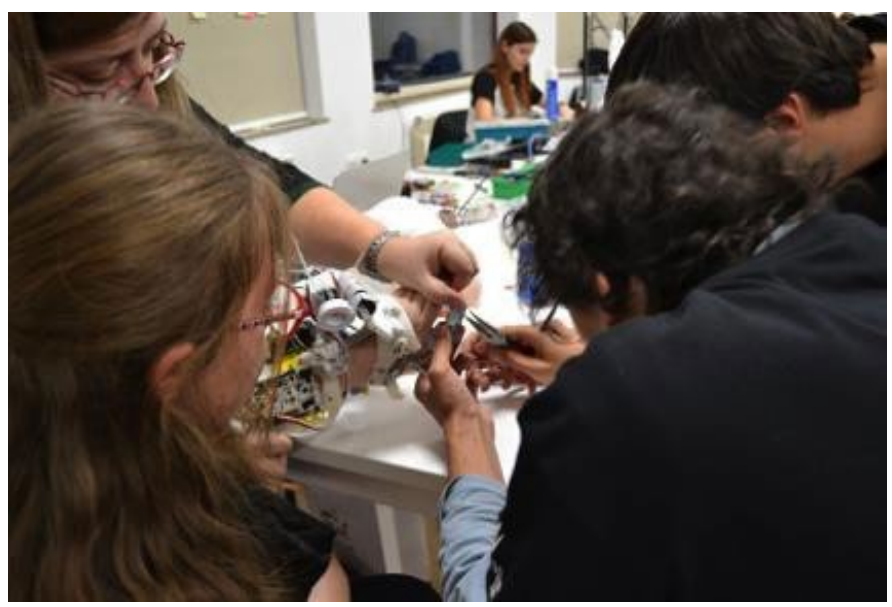

\section{DEBATE AND CONCLUSIONS}

The experience of participation of the University of Salamanca in this type of encounters has shown the interesting benefits that the development of this type of activities can bring in the academic environment, among those outstanding, the social commitment, experimentation with very innovative teaching methodologies and making contact with business work formulas.

For three days, the students manage to work collaboratively and interdisciplinarily, in a practical way and very close to the real professional world. This allows them to greatly enrich their academic and social perspective.

Without a doubt, other great benefits of the participation in this type of initiatives for students is being able to become social innovators, since many of the ideas they propose are truly original and serve as a response to social problems that have not yet been considered or solved. In addition, they acquire a greater sensitivity faced to the great challenges of the World for the coming years, such as the World Sustainable Development Goals set by the ONU, and they feel like getting involved and being part of the group of "solvers" of those great global challenges.

For their part, teachers who get involved in these types of encounters, in addition to sharing this experience with their students in an environment other than the classroom, can pose new challenges that serve to implement teaching innovation in the world of university education.

Undoubtedly, one of the aspects that is very important to highlight is the role of the teaching staff, which in the specific case of MEDIALAB at the University of Salamanca is fundamental. In our experience as organizers, we have been able to verify that the involvement of teachers is very important to motivate students to participate.

\section{ACKNOWLEDGEMENT}

Translated \& edited by American Publishing Services (https://americanpublishingservices.com/). 


\section{REFERENCES}

Almaraz-Menéndez, F., Gimeno-González, M.A., \& Martín-García T. (2016). Emerging digital technologies and new learning spaces. The case of 3D printing at the MEDIALAB of the University of Salamanca. INTED2016 Proceedings, pp. 902-906.

Amable, O., Vivanco-Galván, Castillo, D., \& Jiménez, J. (2018). HACKATHON multidisciplinario: Fortalecimiento del aprendizaje basado en proyectos. Revista CAES. Calidad en la Educación Superior, 9(1), 119-135. https://doi.org/10.22458/caes.v9i1.1893

Cabello, F. (2012). Tirando del ovillo de la red: matrices culturales en el origen de internet. Argumentos de Razón Técnica, 15, 125-154. Retrieved from http://hdl.handle.net/11441/21780

Lucero, M. (2003). Entre el trabajo colaborativo y el aprendizaje colaborativo. Revista Iberoamericana de Educación, 33, 1-20. https://doi.org/10.35362/rie3312923

Martín, G. (2013). El software libre desde el punto de vista de las filosofías de la multiplicidad: Dinámicas de cooperación y trabajo del modelo bazar como modelo alternativo al capitalismo hegemónico. Question, 1(37), 58-70.

Mejía, C. (2007). Formación humanística universitaria: Reto y urgencia de los tiempos modernos. Revista de Investigación UGC, 3, 81-87.

Molina, J.A., García A., Pedraz, A., \& Antón, M.V. (2003). Aprendizaje basado en problemas: Una alternativa al método tradicional. Revista de la Red Estatal de Docencia Universitaria, 3(2), 7985.

Moraga, D., \& Soto, J. (2016). TBL - Aprendizaje Basado en Equipos. Estudios Pedagógicos, 2, 437 447. https://doi.org/10.4067/S0718-07052016000200025

Pedreira, J. (2004, April 22). Los hackers originales. Microsiervos. Retrieved from https://www.microsiervos.com/archivo/internet/los-hackers-originales.html

Raymond, E. (2000, August 25). Breve historia de la cultura hacker. Cultura Informática. Retrieved from https://culturainformatica.es/articulos/breve-historia-de-la-cultura- hacker/

Salcedo, O., Fernández, C.A., \& Castellanos, L. (2011). Hackers en la sociedad de la información: Análisis de su dinámica desde una perspectiva social. Visión Electrónica, 6(1), 115-125.

Sanz-Martos, S. (2017). Hackathon el poder del intercambio de información y el aprendizaje. Anuario Think EPI, 1(1), 274-277. https://doi.org/10.3145/thinkepi.2017.53

Steinbeck, R. (2011). El «design thinking» como estrategia de creatividad en la distancia. Comunicar, 19(37), 27-35. https://doi.org/10.3916/C37-2011-02-02 